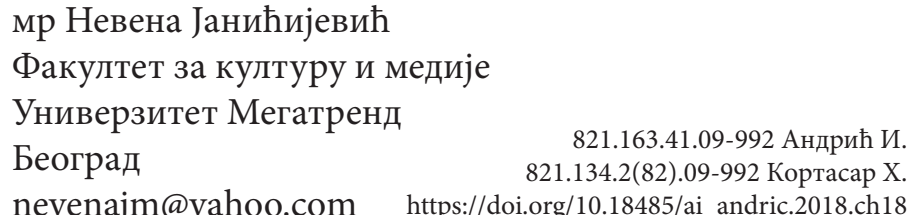

\title{
СЛИКЕ ПРЕДЕЛА И МОСТОВИ У ПУТОПИСИМА ИВЕ АНДРИЋА И ХУЛИЈА КОРТАСАРА
}

Иво Андрић у својим путописима открива тајне медитеранских земаља, задивљен њиховом лепотом, а стари камени мостови настали још у римско доба и обрасли у бршљен причају занимљиве догађаје из прошлости. С друге стране аргентински писац Хулио Кортасар сматра да су мостови везе међу људима, а путујући по свету и описујући пределе по Италији, Француској или Шпанији, стиче се утисак да су људи и народи блискији него што се мисли. Појединац прелазећи мостове, културне и друштвене, упознаје gруїe, а самим тим ствара и једну потпунију слику о самоме себи и вечитој потрази за $g p y$ $\bar{\imath} u$, односно за собом.

Кључне речи: Андрић, Кортасар, путовања, мостови.

Реч 'пут' носи у себи мноштво различитих значења, као што је освајање, другост, забава, знање. Такође односи се на било коју врсту премештања, било оно стварно или фиктивно, може да представља неку врсту животне метафоре или измишљено искуство.

Џејмс Клифорд (James Clifford) у својој књизи Пуйеви даје једну могућу дефиницију, „путовање је термин који садржи широк практични део, мање више вољан, где се напушта кућа да би се отишло на gруі̄o 
место.То премештање за намеру има добит - било материјалну, духовну или научну - и укључује знање или само живљење од тог искуства“"(Clifford, 1997: 66).

Константе путовања по њему су: потрага за другим условљена просторним померањем и као резулат тог процеса је искуство или сазнање. О специфичном односу путовања и културе Џејмс Клифорд (1997: 67) сматра да су путеви један од концепата културе те да дуготрајно инсистирање антропологије на становању и бивствовању у месту, уместо на путовању, може да занемари шири глобални свет интеркултурне размене. Уколико дође до премештања са бивствовања на путовање, како каже Клифорд, онда у први план долазе места премештања интерференције и интеракције. Тако једна култура више није статично тело језгра, већ путничко одредиште или периферија друге културе. А само писање о неком путу постаје виђено као интерактиван процес, између писца и самог дела, оно нема строгу структуру романа већ постаје роман-алманах, који и активно уводи читаоца у саму радњу романа. Клифорд се пита није ли путовање један сложен спектар људског искуства и путника који иде на запад, који тежи међу-културној размени идеја и мишљења (1997:68). Културна акција, како је он зове, стварање нових идентитета се дешава управо у тој зони конйак$\bar{u} a$, на границама нација и земаља. Потрага за нама самима у простору и времену.

У овом раду ћемо се бавити проблемом пута као потрагом и сазнањем код српског писца Иве Андрића и аргентинског писца Хулија Кортасара (Julio Cortázar). Иако просторно и временски удаљени, њихова искуства нам говоре да људи слично реагују на неке земље, поготово на медитеранске, као што су Италија, Шпанија, Португал. 
Слике предела и мостови у путописима Иве Андрића... 309

Иво Андрић креће на студије у Беч, Загреб и Праг и то представља прву етапу у његовом вишедеценијском премештању из места у место. Боравећи негде краће, негде дуже, он ствара слике о пределима и људима које среће на својим путовањима. Српски писац почиње и своју каријеру дипломате у југословенским посланствима, паралелно објављујући и књижевна дела. Што се тиче путописа, први је објавио 1941. године у

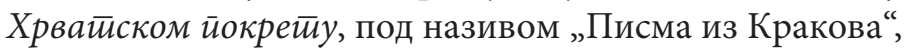
док је студирао на Јагелонском универзитету. Упознаје нове људе и пределе, а 1923. године се сели у Грац. Описе тог времена проведеног у Аустрији ће забележити у тексту „Кроз Аустрију“. Андрић се сем сопственог искуства у путописима ослањао и на податке о самим градовима и земљама које је обилазио или у којима је живео неко време, што због посла, што због студирања. Проучавао је сваки град, пре него што се у њега селио, читао о његовој историји, култури и традицији земље у којој је боравио.

Путовања по медитеранским земљама, као што су Италија, Шпанија и Португал су оставиле јак утисак на писца. Слично искуство је имао и Хулио Кортасар, који је како он сам каже културно емигрирао у Европу почетком педесетих година двадесетог века.

Андрић је своје утиске о пределима и крајевима које је посетио брижљиво записивао, водећи рачуна да сваку земљу представи у својој различитости и богатству у односу на другу. Ипак те медитеранске земље, њене јарке боје, врела лета и благе зиме, раскош и понекад немарност у свакодневном животу су очарале писца. Он пише путописе, а мећу најбољима се издвајају: „Ноћ у Алхамбри“, „Дан у Риму“, „Португал, зелена земља“, „Шпанска стварност и први кораци у њој“ и „Мостови“ које објављује у књизи Сйазе, лица, йpege- 
ли. „Португал, зелена земља“ је објављен 1931. године, а „Шпанска стварност и први кораци у њој“ 1934.

Андрић путује и разгледа, а призори му се чине на тренутке познати, као да је враћен у доба ране младости и детињства. Лисабон је „немирна варош на вулканском тлу“ (Андрић, 1981: 122), али слике рибарица, жена које носе плетене корпе пуне рибе дају сталоженост и неки спокој том узаврелом граду. Португал је земља веселих људи, а посета месту Синтри, где је у краљевском дворцу стварао чувени песник Камоеш, даје путнику осећај нестварне лепоте. „Савршена земља. Гдје закопаш, потече питка вода, а гдје падне семе, ту никне дрво“ (1981: 124), то су речи које су Турци говорили за своје најлепше крајеве, а Андрић сматра да баш одговарају Португалу. На крају каже „Срећни сте и мирни: у Португалу сте“ (1981: 125).

Писац се осећа добро у тим страним земљама, он посматра и проучава њихове обичаје и различитости, а сличности са својом земљом га чине срећним.

У путопису „Шпанска стварност и први кораци у њој“ истиче да је то медитеранска земља, која се својим особинама разликује од Португала. Тамо влада велика врућина, вегетација је бујна и пркоси цивилизацијским прогресима. Писац нам даје слику природе, опчињен њеном лепотом, где на тренутак све стаје у немој тишини, без боја, да би се потом читав предео претворио у неку другу слику. Долазак ноћи мења стварност и види се небо опточено звездама.

У причи „Мостови“ Андрић говори да су они важнији од кућа, светији „где се укрштава највећи број људских потреба“ (1981: 141). То су слике ишчезлих времена, где су људи правили мостове из потребе да се неком приближе или да брже дођу до неког места. Често камени, понекад дрвени, они су показатељ човекове 
Слике предела и мостови у путописима Иве Андрића... 311

умности да савлада препреку, да дође на другу страну, до тог неког gруїоі.

„Тако, свуда на свету, где год се моја мисао крене или стане, наилази на верне и ћутљиве мостове, као на вечиту и вечно незасићену људску жељу да се повеже, измири и споји све што искрсне пред нашим духом, очима и ногама, да не буде дељења, противности, ни растанка.“ (181: 142)

Андрић жели да укаже да су све људске потребе и надања сведени на једну мисао, да се буде заједно, без растанака, да се људи повежу и остану.

Наравно, писац се највише сећа мостова у Босни, у Сарајеву, као и камених мостова у Шпанији или дрвених у Швајцарској. Они причају приче о догађајима и народима који су ту живели. Мостови постају део маште, чежње за сусретом и остајањем, али и прелаз ка gруіом, ка ономе што нас чека и после овог земаљског живота. „Јер све је прелаз, мост чији се крајеви губе у бесконачности, а према ком су сви земни мостови само дечије играчке, бледи симболи.“ (1981: 143-144)

Хулио Кортасар је аргентински писац, ствара и предаје као професор француске књижевности у аргентинским провинцијама, четрдесетих година прошлог века. Потом се враћа у Буенос Ајрес и пријављује се за стипендију за Француску. Почетком 1950. године, одлази у Европу, где ради као преводилац за Унеско. У слободно време он пише, а његово капитално дело Школице $e^{1}$ излази из штампе 1963. године.

Кортасар постаје један од водећих хиспаноамеричких писаца који ствара из Париза, Европе, „погледа увек упртог ка Латинској Америци“ (Кортасар 2010: 147). Париз је за њега Пуй у Дамаск, где открива нове преде-

1 Rayuela 
ле, лица и догађаје, који утичу на њега као писца и као човека. Његове Школице су написане на начин који разбија структуру романа, такозвана нелинеарна проза, где је и читалац део стваралачког процеса. Тај нови начин писања Кортасар је применио и у својим каснијим делима пишући такозване къиіе алманахе, где на необичан и духовит начин даје слику савременог света. Те кюиіе алманаси су и нека врста путописа, али ипак писма које је писао пријатељима у Аргентини су та која на најбољи начин осликавају утиске младог Аргентинца док обилази европске метрополе у Италији или Француској.

Писма ${ }^{2}$ су код Хулија Кортасара била неодвојиви део његовог стваралаштва, а објављена су у пет томова, 2010-2014. године, уз помоћ и подршку његове прве супруге Ауроре Бернардес (Aurora Bernárdez). Он пише о животу, књижевности, политици, уметности, на један топао и људски начин, путујући по читавој Аргентини, а касније и по свету. За Кортасара су писање и путовање радње која се дешавају готово истовремено. Писма су на неки начин његов дневник, она су писање само по себи, без намере да буду књижевно дело. За њега су чак и нека врста светиње, јер увек постоји двоје у писању, онај који чита и онај ко пише. То су интимне поруке, написане спонтано, без претходног размишљања, то су можда најаутентичнији искази његовог бића. Може се рећи да су та писма били његови путописи. Кортасар открива Европу, она је за њега живо биће, па он у писму пријатељици у Аргентини, узвикује: „Европске куће! Како да се не воле, кад су скоро па живе? Векови, обичаји, традиција, су је употпуниле са таквом атмосфером коју само странац може да не примети“3 (2010 :79).

2 Las Cartas

3 ¡ Las casas de Europa! ¿Cómo no quererlas, si están casi vivas? Los siglos, las costumbres, la tradición, la han ido llenado de una atmosfera que solo un extranjero podría ignorar. 
Касније путује у Енглеску због посла. Остаје само шест дана, али и то је довољно да, како Кортасар каже, омирише іраg, та надреална атмосфера која му се деси кад год оде у неки нови град. Он наравно зна да су његова жеља да види неки нови град и стварност самог града две различите ствари. „Дивота је у томе (као у случају Париза) да се открије стварност која је другачија од жеље - јер је боль.“ (2010: 43) Кортасар обилази музеје, посматра уметничка дела, промишља о стваралаштву и даје критичко мишљење о књижевности, уметности, сликарству, музици. У Лондону посећује Галерију Тејт, Националну Галерију и Британски Музеј. Свиђају му се Грци, дела Пјетра де ла Франческе, један недовршени Микеланђело и он све то описује до детаља пријатељу Едуарду Јонкиеру у писмима. Обилази родну кућу песника Џона Китса и износи критичке судове о писању поезије и књижевности уопште. Такође путује по Француској, обилази као прави туриста родну кућу сликара Ван Гога и гроб његовог брата Теофила. Кортасар у Паризу проводи време посећујући књижевне вечери, изложбе, концерте, али и запуштене паришке квартове у којима види не само беду и сиромаштво већ лепоту и једноставност. Путује по Француској, обилази Бурж, Орлеанс где даје детаљан опис витража у катедрали, боравка у хотелу, а шаље и једну од прича о хронопијима и фамама, где на шаљив начин описује обичног, односно необичног возача у сусрету са полицијом на друму. Купује веспу и путује по Француској уживајући у сваком проведеном дану на путу. У децембру долази Аурора Бернандес, његова будућа супруга, а Кортасар у писмима пријатељима описује на духовит начин Париз, град светлости, чаробан град са доковима на Сени, позориштима, музиком, музејима и биоскопима.

„Понекад возећи веспу градом ме нападне нереални осећај, скоро мучан. Шта је то? Шта радим овде? 
За тренутак ме спопадне немир због мог потпуно намерног и сиромашног стања, које је сведено само на садашњост, без икаквог плана. Страх, кајање... А онда се насмејем и прође ме. ${ }^{* 4}$ (2010: 11)

Путује са супругом Аурором у Рим 1953. године, где за прилично скромна средства успева да пронађе пансион у самом центру града на Шпанском тргу. Обилазе ресторане и музеје, шетајући неуморно градом.

Како је диван Рим, тако жут и окер боје, са квадратним крововима и врховима који једва прелазе средину? И пун Италијана који окупирају улице рукама и гласовима, причајући, задовољни (или тужни, не знам, али сви делују задовољно) и одједном на неком путу се нађеш са гомилом мачака, и схватиш да је Рим једна велика жута мачка, која је преко дана спора као Тибар, а преко ноћи се увија и спава и постаје Колосеум. ${ }^{5}$ (2010: 180)

Последњих година живота, Кортасар је писао своје алманахе, а управо таква једна књига, која је објављена само годину дана пре пишчеве смрти (1984), постала је синоним за роман-алманах, али и за путопис.

Мора се имати у виду да је аргентински писац пред крај живота с тим некохерентним формама новог писања (које је започео још у Школицама) желео да

4 A veces conduciendo la vespa me ataca un sentimiento irreal, casi de angustia. ¿Que es eso? ¿Que hago aca? Por un momento me agarra la inquietud por mi estado completamente voluntario y modesto, que esta reducido solo al presente, sin ningún plan. El miedo, el arrepentimiento... Pero entonces me rio y me pasa.

5 Que linda es Roma, toda amarilla, toda ocre, toda llena de techos cuadrados con una puntita que apenas sobresale en el medio, y llenísima de italianos que ivanden las calles con las manos y la voz, hablan y están contentos ( o tristes, no se, pero todos parecen contentos) y de repende en un viaje cualquiera te encotras con montones de gatos, y te das cuenta que Roma es también un gran gato amarillo, que de dia anda despacito disfrazado de Tiber, y de noche se enrosca y duerme y es el Coliseo. 
Слике предела и мостови у путописима Иве Андрића... 315

створи неку нову врсту романа који није могла ни лако да се дефинише. Ауйонауйи на космичком gруму - безвремено йуйовање Париз-Марсељ ${ }^{6}$ је последња књига коју је написао у пару са другом супругом Карол Данлоп (Carol Dunlop), на два језика, француском и шпанском. Кортасар имитира структуру путописа, ту су датуми, описи, топоними, али његово дело није путопис, већ алманах. То је можда покушај да се отпутује у себе самога, да се посматрајући друге открије нешто о себи и да се уз помоћ игре направи модалитет другачијег начина живота. Ова књига представља пост-модерног путника, који је последица постмодерног живота, хаотичног и убрзаног, где се уз путничка искуства откривају основни мотиви људске потребе за кретањем. Есенција термина пут, када реч $\bar{u} y \bar{u}$ прелази из свог чисто материјалног значења (промена места, премештање из једно места у друго, у већини случајева припремљен пут) у неко друго егзистенцијално, духовно, где је живот представљен као пут, а тим и књижевност као пут, то јест писање романа као пут. У књизи се мешају и живот (нека врста биографије) и књижевност, нарација и сам пут, као и измештање у простору и времену. Постоје правила игре, да се са аутопута Париз-Марсељ не сме скренути, тако да брачни пар путује јужним аутопутом, заустављајући се на сваком стопу (има и око 30), док на сваком другом преспава или у мотелу или у комбију којим се возе. Тако путовање траје 30 дана, а Кортасар до детаља описује сваки минут проведен на друму и ван њега. После пар дана супружници постају свесни да је друм све мање важан у читавој причи, а да су догађаји на стоповима оно што чини драж и лепоту путовања. Кортасар истражује природу на паркинзи-

6 Los autonautas de la cosmopista o un viaje atemporal Paris-Marsella 
ма, концепција стварности се мења, тако да необично (живот на паркингу) постаје уобичајено. Композиција странице је врло необична, ту је и текст и слика, а на крају сваког дана и дневник пута. Сам циљ пута није више Марсеј, то иде даље од града Марсеја, што је првобитно била мета, јер он каже да „сваки пут има свој почетак и крај, али путници овог романа су већ стигли на њихово одредиште“" (Кортасар 1983: 190).

Књига прати путовање и развија се заједно са ауторима, то јест учесницима пута. Нарација књиге се смешта између путовања и писања, да се достигне тај други паралелни аутопут, који можда постоји само у машти оних који га сањају.

На крају књиге сазнајемо да Кортасар остаје сам, без партнера у животу. Он је измештен из света и времена, а писање је отворен дијалог са одсутним, са другим, то је знак љубави према преминулој супрузи. Такође писање означава присуство одсутног у gруїом.

На крају књиге он каже „...научила си ме да живим, иако није било довољно времена да то покажемо у овој авантури, која се сада завршава, али и траје, и даље траје у нашем змају ${ }^{8}$, траје заувек на нашем друму“9 (1983: 308).

Сем путовања и мостови су били важна тачка у Кортасаровом књижевном опусу. Још као младић он у писму Луцијен Дипра, каже да су они место сусрета два бића. „Ми смо сами: ми смо острва. Али очајавамо, правимо мостове и све што чинимо - оно религиозно,

7 Cada viaje tiene su comienzo y fin, pero los viajeros de esta novela, ya habían llegado a su destino

8 Комби којим путују, назван змај-Фафнер.

9 ...me enseñaste a vivir como acaso hemos llegado a mostrarlo en esta aventura que toca aquí su término pero que sigue, sigue en nuestro dragón, sigue para siempre en nuestra autopista. 
друштвено, љубавно, притељско - није ништа друго до мостови. ${ }^{10}$ (Кортасар 2010: 78)

У роману Школище, који је и нека врста антиромана, главни јунак Оливеира је у сталној потрази за другим. То тражење се простире од Париза до Буенос Ајреca, а људи које среће су пријатељи и познаници, који свако на свој начин остављају траг на души главног јунака. Сам јунак је и нека врста двојника самог писца, у „потрази за сазнањима о себи са сумњом у моћ сазнања и у исход потраге“, каже Силвија М. Стојаковић у поговору романа (Кортасар 1993: 597). У делу има више двојника, егзистенцијалних трагача, који желе да дођу до одговора, а за то су им потребни мостови. Мостови у мислима, прави мостови који су начин приближавања двоје људи. Постоји чувена сцена из књиге, када главни јунак Оливеира остаје без чаја у кући. Како не може да замисли да мора да изађе из стана, он смишља начин да од комшије (иначе најбољег пријатеља) преко прозора пребаци даску по даску, да је укуца и да тако направљен мост буде начин да се добије чај. Наравно преко даске мора да пређе девојка његовог друга, Талита, која се двоуми да ли да се упусти у тај подухват (јер су станови на спрату). Она креће, и долази до половине и онда схвата да ипак не жели да иде даље. Ова сцена има и дубљи карактер, јер Талита осећа нешто и према Оливеири, па би тај пут преко моста био и нека врста предаје другом човеку. На крају она се ипак враћа свом момку, а Оливеира остаје и без девојке и без чаја.

Кортасар кроз своје јунаке жели да достегне неку нит, повезаност где би у пару, у двоје, они лакше савладали изазове и препреке које им живот намеће. Но, до

10 Estamos solos: somos islas. Pero nos desesperamos por tender puentes, y todas nuestras actitudes- lo religioso, lo social, el amor, la amistad - no son otra cosa que esos puentes. 
краја романа, одговора нема јер Оливеира остаје сам, можда јер тежи ка савршенству, иако зна да оно није са овога света.

Иво Андрић и Хулио Кортасар су, сваки на свој начин, писали и описивали крајеве, пределе и земље кроз које су пролазили, негде се задржавајући дуже, негде краће. Оба писца на сличан начин су била одушевљена и очарана медитераном, Италијом, Шпанијом, Француском. Те земље су за њих пуне историје и неке необичне људске блискости, а обичан свет им ипак показује да су људи свугде слични. Ти мостови, било људски, било од камена или дрвета, ту су да спајају људе, да их приближе једни другима и да час растанка никада не дође.

На крају, можда путовања могу да буду мостови што спајају људе, где се лакше подноси пут и живот којим идемо.

\section{Извори и литература}

Андрић, Иво. Сйазе, лица, ӥреgели. Сабрана gела Иве Анgрића, дойуюено изgаюе, књиіа gесейа. Београд, Сарајево: Просвета, Свјетлост, 1981.

Clifford, James. Routes, Travel and Translation in the Late Twentieth Century. Cambridge, Massachusetts: Harvard University Press, 1997.

Cortázar, Julio. Los autonautas de la cosmopista o un viaje atemporal Paris-Marsella. Buenos Aires: Muchnik Editores, 1983.

Cortázar, Julio. Las Cartas, I $-V$ tomo. Buenos Aires: Alfaguara, 2010-2012

Cortázar, Julio. Álbum Cortázar de la A a la Z. Un álbum biográfico. Buenos Aires: Alfaguara, 2014.

Кортасар, Хулио. Школище. Београд: Bata: North: American: Orbis, 1993. 
Слике предела и мостови у путописима Иве Андрића... 319

Nevena Janićijević

\section{IMAGES OF REGIONS AND BRIDGES IN THE TRAVELS OF IVO ANDRIĆ AND HULIO KORTASAR}

\section{Summary}

In his travels, Ivo Andrić reveals the secrets of the Mediterranean countries, amazed by their beauty, and the old stone bridges that emerged back in the Roman period talking about interesting events from the past. On the other hand, Argentine writer Hulio Kortasar thinks that bridges are ties between people, and traveling around the world and describing areas in Italy, France, or Spain, the impression is that people and peoples are closer than they think. An individual crossing cultural and social bridges, meets the "others", and thus creates a more complete picture of himself and the eternal pursuit for «other», or for himself.

Key words: Andrić, Kortasar, travels, bridges. 